\title{
The Global Scenario of A1, A2 $\beta$-Casein Variant in Cattle and its Impact on Human Health
}

\author{
Neena Amatya Gorkhali ${ }^{\S}{ }^{*}$ Chhiring Sherpa ${ }^{\S}$, Prashanna Koirala ${ }^{\S}$, Saroj Sapkota, and Bhoj Raj \\ Pokharel \\ $\S$ These authors have equal contribution \\ National Animal Breeding and Genetics Research Centre, Nepal Agricultural Research Council (NARC), Nepal
}

\begin{tabular}{l} 
M A N U S C R I P T I N F O \\
\hline Article history: \\
Received 9 August 2020 \\
Received in revised form 1 June 2021 \\
Accepted 29 June 2021 \\
\hline Keywords: \\
A1 and A2 $\beta$-casein \\
Cattle \\
Milk \\
Human diseases \\
Globe \\
\hline
\end{tabular}

\begin{abstract}
A B S T R A C T
Beta casein ( $\beta$-casein) has gained considerable interest among scientists and farmers as it provides promising factors to milk that enhance its quality and concentration. It is believed that the A1 $\beta$-casein variant shares an association with numerous human diseases. Since there are numerous hypotheses concerning the link between variants of $\beta$-casein and human diseases, many researchers across the globe have genotyped the cattle in terms of A1, A2 $\beta$-casein variants. This paper catalogs the A1 and A2 $\beta$-casein genotypes shared by different cattle breeds across the globe. Various literature encompassing the adverse effects of $\beta$-casein variants were assessed adequately. This paper suggests that the effects of undertaking the A1 $\beta$-casein variant on human health are ambiguous. Adequate research providing stronger evidence is needed for understanding the effects imparted by the consumption of both A1 and A2 $\beta$-casein variants on human health.
\end{abstract}

(c) 2021 NAPA. All rights reserved.

Citation:

Gorkhali, N.A., Sherpa, C., Koirala, P., Sakpota, S., \& Pokharel, B. R. (2021). The global scenario of A1, A2 $\beta$-Casein variant in cattle and its impact on human health. Global Journal of Agricultural and Allied Sciences, 3(1), 16-24.

\section{Introduction}

Milk and the related dairy products obtained from animals have contributed as pivotal ingredients of the human diet. Besides providing nutrition, milk contributes to numerous other biological activities like specific organ growth and development, enhances disease resistance ability, and promotes digestive functions and various metabolic responses (Schanbacher, Talhouk, Murray, Gherman, \& Willett, 1998). Proteins and peptides present in milk are likely to be responsible for biological activities which may be present either naturally in milk or the form of digested protein in the gastrointestinal tract (Xu, 1998). However, the composition of these nutrients varies depending on animal species and breeds, geographical composition, and newborn needs.

The total protein content in milk is about $3.5 \%$ (Miller, Jarvis, \& McBean, 2006). Casein and whey protein, two major protein groups, are found in cow's milk among which caseins constitute $80 \%$ of milk proteins (Groenen \& van der Poel, 1994) and whey proteins form about $14 \%$ of the bovine milk proteins (McLachlan, 2001). Whey proteins are soluble proteins. The protein fraction comprises $\beta$-lactoglobulin, $\beta$-lactalbumin, bovine serum albumin, and immunoglobulin while protease, peptone, and nitrogen compounds make up the non-protein portion. Caseins are the major fraction of the protein present in milk. There are 4 types of casein

\footnotetext{
*Corresponding author. E-mail address: neenagorkhali@hotmail.com
}

present in bovine milk, as1 (CSN1S1) accounting for $39-46 \%$ of total caseins, $\alpha$ s2 (CSN1S2) at $8-11 \%, \beta(\mathrm{CSN} 2)$ at $25-35 \%$, and $\kappa(\mathrm{CSN} 3)$ at $8-15 \%$ (Farrell et al., 2004). All these four casein genes are located on chromosome 6 found between $200 \mathrm{~kb}$ to $300 \mathrm{~kb}$ of DNA (Ferretti, Leone, \& Sgaramella, 1990). Casein is found as a rich source of bioactive peptides that have been reported to exhibit various physiological functions such as opioid agonists and antagonists, immune-regulation (Korhonen \& Pihlanto, 2003), antimicrobial activities (Atanasova \& Ivanova, 2010), antioxidant properties, antihypertensive, and hypo-cholesterolemic effects.

Bovine milk dominates global milk production as it is the most commonly consumed milk. A1 milk is commonly found in cattle of crossbred and European breeds while the A2 protein variant is common in the milk of indigenous cattle of Asia. While both A1 and A2 variants are observed in Holstein Friesian and Jersey breeds across the world, the A2 type is more dominant in Jersey but the opposite is true in Holstein. It was found that the distribution and frequency of cattle with A1 and A2 milk types were area-specific rather than breed-specific.

$\beta$-casein variants have been the subject of interest to the scientific community because it influences the technological properties of milk and human health. The role of $\beta$-casein variants in cheese quality is important as its concentration is positively associated with good rennet properties of milk (Massella et al., 2017). It is reported that the quality and yield of cheese rely on variants of $\beta$-casein (Dinc, Ozkan, Koban, \& Togan, 2013). More importantly, $\beta$-casein imparts a significant role in increasing casein 
in milk (Ketto et al., 2017). A1 and A2 variants have been associated with small or large casein micelle size (Day, Williams, Otter, \& Augustin, 2015). $\mathrm{A} 1$ variant is considered better than the $\mathrm{A} 2$ variant in improving rennet coagulation (Heck et al., 2009).

$\beta$-casein variants impart instrumental properties in milk and are also believed to be associated with numerous diseases. Researchers have found possible relation between milk consumption and some diseases such as type-1-diabetes, cardiovascular disease, sudden infant death syndrome, schizophrenia and autism, gastrointestinal disease, prostate cancer, and other diseases (Chia et al., 2017; Kamiński, Cieślińska, \& Kostyra, 2007; Kaskous, 2020; Pal, Woodford, Kukuljan, \& Ho, 2015; Sheng, Li, Ni, \& Yelland, 2019; Sodhi, Kataria, Joshii, Mukesh, \& Mishra, 2012). Peptides present in the milk have been suggested to cause negative effects on human health. Subsequently, they have gained considerable attention in the scientific world.

There has been an increasing trend of importing different exotic cattle breeds to Nepal such as Holstein Friesian and Jersey for fulfilling the demand for milk as they produce a larger volume of milk. Random cross breeding of indigenous cattle with exotic breeds has been commonly observed. The objective of this review is to identify all relevant studies that evaluate the consumption of A1 $\beta$-casein with health-related outcomes in humans. Ultimately, we aim to control future health risks of populations and prevent cross-breeding of exotic breeds with pure A2 indigenous breeds to make people aware of the conservation of native cattle.

\section{Genetic variants of $\beta$-casein ( $\beta$-casein polymorphism)}

$\beta$-casein consists of 209 amino acids and is the second most abundant casein protein of bovine milk. Change in certain amino acids at various positions in the $\beta$-casein protein gives rise to 12 different variants named $\mathrm{A} 1, \mathrm{~A} 2, \mathrm{~A} 3$, B, C, D, E, F, H1, H2, I, and G (Table 1) (Farrell et al., 2004). Among these 12 variants, $A 1$ and $A 2$ are the most common type of $\beta$-casein among dairy cattle while variant B is the less common type (Kamiński, Ruść, \& Cieślińska, 2006). In the European herds, it is also documented that the mutagenesis has produced $\mathrm{A} 1 \beta$-casein where $\mathrm{A} 2 \beta$-casein protein has been considered the original and more dominant $\beta$-casein protein (Beales et al., 2002).

A2 shows some resemblance to human $\beta$-casein than A1 in terms of digestive breakdown (Barnett, McNabb, Roy, Woodford, \& Clarke, 2014). $\mathrm{A} 1$ and $\mathrm{A} 2 \beta$-casein have secondary structural differences of the expressed protein at position 67 in a chain of 209 amino acids (Elliott, Harris, Hill, Bibby, \& Wasmuth, 1999; McLachlan, 2001). This variation is believed to be caused by a natural point mutation on exon VII of the bovine $\beta$-casein gene on the 6th chromosome and is viewed as Single Nucleotide Polymorphism (SNP) triggering a conversion of cytosine to adenine that leads to substitution of proline (codon: CCT) by histidine (codon: CAT) at position 67 in A1 $\beta$-casein. As a result of this point mutation, $A 2 \beta$-casein has the amino acid proline at position 67 while A1 $\beta$-casein has a histidine amino acid in that position.

DNA-based techniques like Polymerase Chain Reaction - Restriction Fragment Polymorphism (Miluchova, Gabor, \& Trakovicka, 2014), Polymerase Amplification created Restriction site (ul Haq, Kapila, Sharma, Saliganti, \& Kapila, 2014), and Single-Stranded Conformational Polymorphism (Barroso, Dunner, \& Cañón, 1999) can be used to observe these alleles. In terms of digestive breakdown, A2 is more like a human $\beta$ casein than A1 (Barnett et al., 2014).

Table 1. $\beta$-casein variants exhibiting the difference in the sequence of an amino acid (Farrell et al., 2004).

\begin{tabular}{|c|c|c|c|c|c|c|c|c|c|c|c|c|c|c|}
\hline \multirow{2}{*}{$\begin{array}{l}\text { Variants of } \\
\beta \text {-casein }\end{array}$} & \multicolumn{14}{|c|}{ The difference in amino acids sequence } \\
\hline & 18 & 25 & 35 & 36 & 37 & 67 & 72 & 88 & 93 & 106 & 117 & 122 & 137 & 138 \\
\hline $\mathrm{A} 1$ & Ser-P & Arg & Ser-P & Glu & Glu & His & Glu & Leu & Gln & His & Gln & Ser & Leu & Pro \\
\hline A2 & & & & & & Pro & & & & & & & & \\
\hline A3 & & & & & & Pro & & & & Gln & & & & \\
\hline B & & & & & & His & & & & & & Arg & & \\
\hline C & & & Ser & & Lys & His & & & & & & & & \\
\hline D & Lys & & & & & Pro & & & & & & & & \\
\hline E & & & Lys & & & Pro & & & & & & & & \\
\hline $\mathrm{F}$ & & & & & & His & & & & & & & & Leu \\
\hline H1 & & Cys & & & & Pro & & Ile & & & & & & \\
\hline $\mathrm{H} 2$ & & & & & & Pro & Glu & & Leu & & & & & Glu \\
\hline I & & & & & & Pro & & & Leu & & & & & \\
\hline $\mathrm{G}$ & & & & & & His & & & & & & Leu & & \\
\hline
\end{tabular}

\section{Genotypes of $\beta$-casein variants in different cattle breeds across the world}

Numerous studies in assessing the genotype of cattle concerning the A1 or A2 variant have been conducted across the globe (Dinc et al., 2013; Dai et al., 2016; Gorkhali et al., 2020). A2 homozygous is predominantly found in most Indian cattle (Gir, Hariana, \& Kangayam) (Sodhi et al., 2012).
Similarly, Lulu, one of the highland cattle and native breeds of Nepal, also shares a high A2 homozygous genotype (Gorkhali et al., 2020). However, the cattle from western countries (Denmark, Slovakia) have either A1 dominant genotype or an equal proportion of A1 and A2 variants of $\beta$ casein (Gustavsson et al., 2014; Miluchova et al., 2014). Some of the cattle breeds that have been genotyped across the globe concerning $\beta$-casein variants are documented in Table 2 . 
Table 2. A1, A2 $\beta$-casein variants genotype in different cattle breeds around the world.

\begin{tabular}{|c|c|c|c|c|c|c|c|c|}
\hline $\mathbf{S N}$ & Breed & Country & A1 & A2 & A1A1 & $\mathbf{A 1 A 2}$ & A2A2 & Reference \\
\hline 1 & Amritmahal & India & 0 & 1 & 0 & 0 & 1 & (Sodhi et al., 2012) \\
\hline 2 & Anatolian Black & Turkey & 0.132 & 0.765 & - & - & - & (Dinc et al., 2013) \\
\hline 3 & Eastern Anatolian Red & Turkey & 0.118 & 0.824 & - & - & - & (Dinc et al., 2013) \\
\hline 4 & Gir & India & 0 & 1 & 0 & 0 & 1 & (Sodhi et al., 2018) \\
\hline 5 & Hariana & India & 0 & 1 & 0 & 0 & 1 & (Sodhi et al., 2018) \\
\hline 6 & Holstein & Slovakia & 0.3678 & 0.6322 & 0.1379 & 0.4598 & 0.4023 & (Miluchova et al., 2014) \\
\hline 7 & Holstein Candidate Bulls & Turkey & 0.278 & 0.722 & - & - & - & (Dinc et al., 2013) \\
\hline 8 & Holstein & China & 0.432 & 0.459 & 0.203 & 0.353 & 0.226 & (Dai et al., 2016) \\
\hline 10 & Holstein & Netherlands & 0.28 & 0.50 & - & - & - & (Visker et al., 2011) \\
\hline 11 & Holstein & Netherlands & 0.029 & 0.69 & - & - & - & (Heck et al., 2009) \\
\hline 12 & Holstein & Poland & 0.32 & 0.68 & - & - & - & (Cieślińska et al., 2012) \\
\hline 13 & Holstein & Poland & 0.35 & 0.65 & - & - & - & (Cieślińska et al., 2012) \\
\hline 14 & Holstein & Thailand & 0.363 & 0.602 & - & - & - & (Molee, Boonek, \& Rungsakinnin, 2011) \\
\hline 15 & Holstein & Italy & 0.371 & 0.546 & & & & (Massella et al., 2017) \\
\hline 17 & Holstein & Turkey & 0.485 & 0.456 & - & - & - & (Dinc et al., 2013) \\
\hline 18 & Holstein & Poland & 0.40 & 0.60 & - & - & - & (Kamiński et al., 2006) \\
\hline 19 & Holstein & Italy & 0.395 & 0.57 & - & - & & (Chessa, Bulgari, Rossoni, Ceriotti, \& Caroli, 2013) \\
\hline 0 & Kangayam & India & 0 & 1 & 0 & 0 & 1 & (Sodhi et al., 2012) \\
\hline 21 & Kankrej & India & 0 & 1 & 0 & 0 & 1 & (Sodhi et al., 2018) \\
\hline 22 & Kherigarh & India & 0.109 & 0.891 & 0 & 0.218 & 0.783 & (Sodhi et al., 2018) \\
\hline 23 & Ladakhi cattle & India & 0.10 & 0.90 & 0 & 0.79 & 0.21 & (Sodhi et al., 2018) \\
\hline 24 & Lulu & Nepal & 0.03 & 0.97 & 0 & 0.06 & 0.94 & (Gorkhali et al., 2020) \\
\hline 25 & Malnad Gidda & India & 0.096 & 0.904 & 0 & 0.191 & 0.809 & (Sodhi et al., 2018) \\
\hline 26 & Malvi & India & 0 & 1 & 0 & 0 & 1 & (Sodhi et al., 2018) \\
\hline 27 & Mewati & India & 0 & 1 & 0 & 0 & 1 & (Sodhi et al., 2018) \\
\hline 28 & Nimari & India & 0 & 1 & 0 & 0 & 1 & (Sodhi et al., 2018) \\
\hline 29 & Pinzgau breed & Slovakia & 0.5640 & 0.4360 & 0.3023 & 0.5233 & 0.1744 & (Miluchova et al., 2014) \\
\hline 30 & Polish Holstein-Friesian & Poland & & & 0.124 & 0.389 & 0.485 & (Cieślińska et al., 2012) \\
\hline 31 & Rathi & India & 0 & 1 & 0 & 0 & 1 & (Sodhi et al., 2018) \\
\hline 32 & Red Kandhari & India & 0 & 1 & 0 & 0 & 1 & (Sodhi et al., 2018) \\
\hline 33 & Red Sindhi & India & 0 & 1 & 0 & 0 & 1 & (Sodhi et al., 2018) \\
\hline 34 & Red & Sweden & 0.48 & 0.51 & - & - & - & (Gustavsson et al., 2014) \\
\hline 35 & Red & Poland & 0.53 & 0.47 & - & - & - & (Cieślińska et al., 2019) \\
\hline 36 & Red & Denmark & 0.71 & 0.23 & - & - & - & (Bech \& Kristiansen, 1990) \\
\hline 37 & Sahiwal & India & 0 & 1 & 0 & 0 & 1 & (Sodhi et al., 2018) \\
\hline 38 & Slovak Spotted & Slovakia & 0.298 & 0.7072 & 0.1261 & 0.333 & 0.5406 & (Miluchova et al., 2014) \\
\hline 39 & Southern Anatolian Red & Turkey & 0.117 & 0.766 & - & - & - & (Dinc et al., 2013) \\
\hline 40 & Tharparka & India & 0 & 1 & 0 & 0 & 1 & (Sodhi et al., 2018) \\
\hline 41 & Turkish grey & Turkey & 0.426 & 0.544 & - & - & - & (Dinc et al., 2013) \\
\hline 42 & Turkish Holstein & Turkey & 0.485 & 00.456 & - & - & - & (Dinc et al., 2013) \\
\hline
\end{tabular}

\section{A1 versus A2 milk}

Over several centuries domesticated cows produced milk rich in $\beta$-casein A2. Milk containing A2 $\beta$-casein showed no deleterious effect on human health. However, the natural mutation, especially in the number of European cattle showed expression of A1 $\beta$-casein in produced milk. This mutation gradually started dominating more cattle resulting in the production of A1 milk. Exotic or crossbreed cattle frequently showed the A1 allele while native cattle showed only the A2 allele (Sodhi et al., 2018). Milk containing the A1 protein variant is commonly produced by crossbreed or European breeds of cattle such as Holstein, Jersey, and Friesian. A1 $\beta$-casein variant is assumed to be unsuited for consumption and thus the dairy cows are chosen based on $\beta$-casein polymorphism. Different screening programs were conducted among dairy breeders to support the A2 variant. In New Zealand cowherds producing milk with just A2 variant were chosen to initiate the marketing of A2 milk in 2003 (Kamiński et al., 2007)

Prof. Bob Elliot, the Auckland diabetes specialist, was the first scientist to initiate the research correlating A1 $\beta$-casein and its impact on human health after he observed the 10 fold difference in the incidence of Type 1 diabetes between Samoan children living in New Zealand and those living in Samoa. With his previous research experience that showed casein or some other unknown component was responsible to cause diabetes in rodents, he identified milk as a potential candidate for causing this disease. Later, NZ Dairy Research Institute found protein differences in the milk (i.e., $\beta$-casein protein) consumed by the people living in Kenya and New Zealand. This led to an assumption that perhaps A1 $\beta$-casein protein is associated with the causation of type 1 diabetes, but the mechanism related to this was unclear (Woodford, 2008). 


\section{Milk and $\beta$-Casomorphins (BCMs)}

Proteins that are involved in various important biological processes release some physiologically active peptides (bioactive) following their enzymatic hydrolysis during digestion or other processes. In-vivo or in-vitro digestion of $\beta$-casein produces BCMs. BMCs are peptides having 4-11 amino acid chain lengths and start with tyrosine residue at position 60 . The release of this exogenous opioid peptide occurs through the incomplete digestion of A1 $\beta$-casein (Phelan, Aherne, FitzGerald, \& O’Brien, 2009). BCM-7 and BCM-5 are the most active out of all BMCs and represent fragments of $\beta$ casein as f60-66 and f60-64, respectively (Kamiński et al., 2007). Bovine $\beta$-casomorphins give rise to bioactive peptides that exhibit different properties like anti-microbiological, antithrombotic, antioxidant, immunomodulatory, and mineral-binding activities (Clare \& Swaisgood, 2000; Phelan et al., 2009). These $\beta$-casein derived peptides bind to $\mu$ receptors located in the central nervous system, gastrointestinal tract, and some immune cells and thus show opioid and pharmacological activities (Teschemacher, 2003). They are found to play a role in several biological processes that include respiration, constipation, analgesia, and behavior in humans (Farrell et al., 2004).

The difference between A1 and A2 $\beta$-casein variants is a single amino acid substitution at the 67 th residue of the 209 amino acid chain. This change claimed a major effect in terms of BCM release liberating digested opioid peptide $\mathrm{BCM}-7$ from $\mathrm{A} 1 \beta$-casein and other A1 relating variants. BMC-7 is released by the action of gastrointestinal enzymes like pepsin, elastase, etc. on A1 milk which is due to the cleavage of histidine at the 67 th position, whereas, A2 variants hinder the cleavage at this $67^{\text {th }}$ position due to the presence of proline instead of histidine preventing the formation of BCM-7. As shown in Figure 1, the peptide bond between isoleucine and histidine is cleaved by elastase which results in the liberation of the carboxyl terminus of BCM-7. Likewise, the amino terminus of this peptide is released by pepsin and leucine (Farrell et al., 2004).

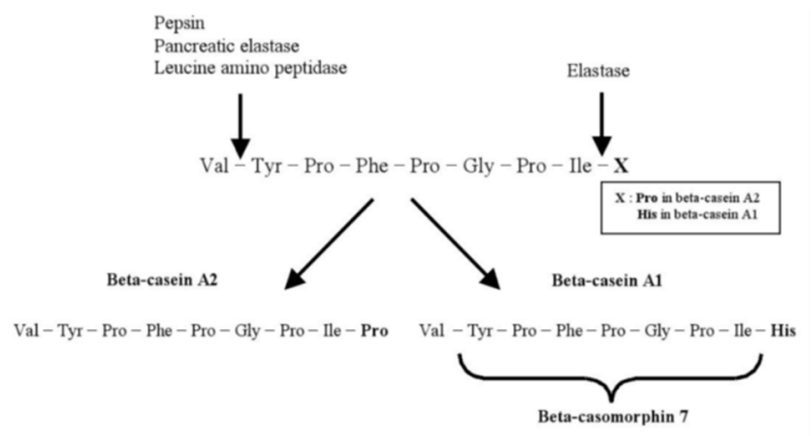

Figure 1: BCM-7 produced from $\beta$-casein variant A1 (Kamiński et al., 2007)

BCM-7 is also considered hazardous to human health and is likely to be associated with diseases like human ischemic heart disease, type 1 diabetes, atherosclerosis, sudden infant death syndrome, schizophrenia, autism, etc. as shown in Table 3. Thus, metaphorically BCM-7 is debated as the 'devil in the milk' (Woodford, 2008). Protection against hyperglycemia and free radical-mediated oxidative stress (Yin, Miao, \& Zhang, 2010), expression of mucin gene and secretion of mucus (Trompette et al., 2003), increased prolactin levels (Nedvídková, Kasafírek, Dlabač, \& Felt, 2009) and improved gastrin expression (Zong, 2007) are some beneficial role of BCMs. Likewise, BCMs-5 was found to show cardio-protective function and improvement in memory function as well as learning imbalances in mice (Sakaguchi, Koseki, Wakamatsu and Matsumura, 2003).

Table 3: BCMs associated with diseases (Reddy, Reddy, Ramadevi, \& Kumar, 2016).

\begin{tabular}{ll}
\hline $\begin{array}{l}\text { Disease-associated with milk } \\
\text { consumption }\end{array}$ & Source \\
\hline $\begin{array}{l}\text { Type 1 diabetes, cardiovascular } \\
\text { diseases }\end{array}$ & $\begin{array}{l}\text { (Beales et al., 2002; Elliott et al., 1999; } \\
\text { McLachlan, 2001; Thorsdottir et al., 2000; } \\
\text { Virtanen et al., 2000) }\end{array}$ \\
Arteriosclerosis & (Tailford, 2003) \\
Schizophrenia and autism & (Woodford, 2006) \\
Sudden infant death syndrome & (Sun \& Cade, 1999; Sun et al., 2003) \\
Ischemic heart disease & (McLachlan, 2001) \\
\hline
\end{tabular}

\section{Variants of beta-casein associated with human health}

The hypothesis was formulated concerning the adverse effects of the A1 variant of beta-casein in milk on human health (Elliott et al., 1999; McLachlan, 2001). It was reported that A1 milk is associated with numerous kinds of diseases such as type 1 diabetes, coronary heart disease, autism, and schizophrenia. Many epidemiological studies have revealed the relationship between A1 milk consumption and the incidence of various diseases (Boztepe, Aytekin, \& Şahin, 2018; Cieślińska et al., 2019; Jianqin et al., 2015; Kay et al., 2021; Park \& Haenlein, 2021; Singh, Kour, \& Sharma, 2016; Yadav et al., 2020).

\subsection{Cardiovascular disease (CVD)}

McLachlan highlighted that consumption of A1 $\beta$-casein milk imparts the chances of occurrence of coronary heart disease and intake of this milk protein for a long time would be a risk factor for ischemic heart disease (McLachlan, 2001). This study showed a significant correlation between the consumption of the A1-milk protein and heart disease incidence for 3069 years old males across 16 different countries ( $\mathrm{r} 0.86$ ) postulating that $\mathrm{A} 1$ protein or BCM-7 peptide fragments may contribute to the etiology of cardiovascular disease (Kaskous, 2020; McLachlan, 2001). Another study claimed the establishment of an association between A1 milk consumption and its unfavorable role in ischemic heart disease (Beales et al., 2002). In addition, Tailford (2003) reported a higher amount of serum cholesterol in rabbits that were given $\mathrm{A} 1 \beta$-casein and found that $\mathrm{A} 1$ milk consumption promoted fat build-up in the blood vessels at a higher rate making it more atherogenic as compared to A2 $\beta$-casein. Reduced serum cholesterol was found in the rabbits that were fed with A2 $\beta$-casein. The physiological effect of BCM-7 on the oxidation of low-density lipoprotein (LDL) as a causative factor for heart diseases (Elliott et al., 1999).

On the contrary, no convincing evidence between A1 milk and human health while reviewing the effects of A1 $\beta$-casein (Truswell, 2005). It was 
concluded that consumption of A1 milk does not have any cardiovascular health disadvantage over the milk containing A2 $\beta$-casein (Sheng et al., 2019).

Several studies have reported the incidence of cardiovascular disease (CVD) with the consumption of milk $\beta$-casein. However, there is no strong evidence to prove the adverse effects of A1 milk on the physiology of the heart. Thus, further studies are required to examine the long-term effects of different casein proteins present in milk.

\subsection{Type-1 diabetes (T1D)}

This disease is characterized by the inability of the body to produce sufficient insulin through the destruction of beta cells of the pancreas by the immune system of the host. The role of milk containing A1 $\beta$-casein in the onset of type-1 diabetes has been a controversial issue for decades. BCM-7 derived from $\beta$-casein may function as an immunosuppressant and reduce tolerance to dietary antigens in the gut immune system leading to the onset of T1D (Clemens, 2011). Several studies have shown the increased incidence of type- 1 diabetes with the consumption of milk containing $\beta$ casein variants. Elliott et al. (1999) critically viewed the occurrence of type1 diabetes among 0-14 years old children who were fed with A1 $\beta$-casein milk in Polynesian Island and observed a moderate correlation $(\mathrm{r}=0.726)$ between the incidence of type-1 diabetes and consumption of A1 milk. Further experiments on mice were employed for assessing the effects of A1-type milk. All the experiments performed by Elliott pinpointed the association between numerous diseases with A1 $\beta$-casein. McLachlan, (2001) also observed a strong association between A1 $\beta$-casein consumption and incidence of diabetes while studying the effects of A1 milk in children of different ages in Northern Ireland. In addition, Chia et al. (2017) presented A1 $\beta$-casein as a primary causal trigger of type-1 diabetes in individuals with genetic risk factors. Also, Malmström et al. (2010) reported evidence of diabetes amongst genetically susceptible children of Finland who consumed A1 milk. Similarly, lactose malabsorption and digestive discomfort with lactose-containing milk were improved with the use of A2 $\beta$-casein milk in lactose-intolerant individuals (Milan et al., 2020). However, studies on other animals have shown no difference in effect between A1 and A2 milk with regards to the incidence of type-1 diabetes (Beales et al., 2002; Yin, Miao, Ma, Sun, \& Zhang, 2012)

\subsection{Gastrointestinal Disease}

Several studies have reported that increased consumption of dairy products is related to an increased incidence of gastrointestinal disorders. The proteolysis of $\beta$-casein (BCM-7) present in milk that forms a group of peptides has been attributed to the cause of some of these effects of dairy products. These active peptides have been found to interact with $\mu$ receptors of the gastrointestinal tract and exhibit an effect on gastrointestinal motility in adults and neonates (Baldi et al., 2005). BCM-7 is found to activate $\mu$-opioid receptors expressed throughout the gastrointestinal tract and can cross the gastrointestinal wall to enter and influence the systemic and cellular activities to affect gut motility, absorption, secretion, and immune function (Pal et al., 2015). It is hypothesized that the consumption of A1 milk triggers the production of BCM-7 which in turn gets exposed to tissues and exerts a range of proinflammatory effects including altered signaling activity, redox disorders, and altered epigenetic regulation of gene expression (Trivedi et al., 2014). These changes are responsible for inducing disturbance in the digestive process to cause gastrointestinal disorder which is reported as symptoms of lactose intolerance (Jianqin et al., 2015). Further, these bioactive peptides were found to alter mucus secretion of mucus-secreting cells present in the intestine (Zoghbi et al., 2006). Liu \& Udenigwe (2019) reported the role of opioid peptides in the gastrointestinal system. Pal et al. (2015) observed that A1 milk significantly increased gastrointestinal transit time, production of dipeptidyl peptidase-4, and the inflammatory marker myeloperoxidase in rodents to A2 milk. A study of 41 men and women demonstrated that milk containing A1 $\beta$-casein led to significantly higher stool consistency values showing a remarkable association between abdominal pain and stool consistency ( $\mathrm{r}=0.52)$ compared with A2 milk $(\mathrm{r}=-0.13)$ (Ho et al., 2014). In a study on rats, Barnett et al. (2014) reported the direct effect on gut function by the consumption of A1 milk via both opioid-dependent and opioid-independent pathways. In addition, Haq et al. (2014) confirmed that A1 $\beta$-casein induces an inflammatory response in the gut to show its negative impact by activating the pathways. Likewise, Jianqin et al. (2015) confirmed the association of A1 $\beta$-casein with greater post-dairy digestive discomfort symptoms; higher concentrations of inflammation-related biomarkers and $\mathrm{BCM}-7$; longer gastrointestinal transit times and lower levels of short-chain fatty acids. Milk containing A1 $\beta$-casein was found to reduce lactase activity and increase gastrointestinal symptoms, while A2 milk was found to weakened acute gastrointestinal symptoms of milk intolerance (He, Sun, Jiang, \& Yang, 2017). Further animal research and clinical trials on the role of A1 $\beta$-casein in gastrointestinal disorders are needed.

\subsection{Sudden Infant Death Syndrome (SIDS)}

Sudden infant death syndrome is the death of an infant within the first year of life. It appears that casein-derived peptides as BCM-7 play a role in SIDS. BCM-7 can affect various opioid receptors in the immune, nervous, and endocrine systems. Milk can be considered as the common nutrient source for all children developing this syndrome. Sun et al. (2003) observed that BCM-7 from the immature gastrointestinal tract of the infant passes into the blood and crosses the blood-brain barrier because of the infant's immature central nervous system. It has been reported that the BCM-7 immune response takes place in the brainstem of human infants (Sun et al., 2003; Whiteley et al., 2010). The opioid peptides present in milk could induce depression of the brain-stem respiratory centers causing deaths in infants with abnormal respiratory control and vagal nerve development. Infants may absorb BCM-7 due to the juvenile gastrointestinal tract and these peptides can potentially affect various opioid receptors in the nervous, endocrine, and immune systems (Bell, Grochoski, \& Clarke, 2006). In addition, (Wasilewska et al., 2011) reported a higher amount of BCM-7 in sera of some infants after an apnoea than that of healthy infants of the same age. Further investigation exploring the relation of casein-derived peptides and SIDS is warranted.

\subsection{Neurological Disorders}

Neurological disorders such as autism and schizophrenia are associated with the consumption of milk containing A1 $\beta$-casein (Sun \& Cade, 1999). An increase in the level of BCM-7 was observed in the urine and blood of 
some autism and schizophrenia patients. It is hypothesized that the exogenous opioids derived from the incomplete digestion of casein and gluten protein can soak across the gastrointestinal system to enter the blood circulation and become biologically active through opioid receptor binding and thus magnify symptoms in individuals suffering from neurological disorders (Buie et al., 2010). In addition, one study demonstrated that the autistic behavior of individuals may be improved by decreasing casein and gluten in the diets of people with autism (Chia et al., 2017). Several studies have shown improvement of these diseases with the consumption of a diet free from casein and gluten (Kost et al., 2009; Whiteley et al., 2010). However, (Cass et al., 2008) claimed that opioid peptides cannot be used as a biological marker for autism or be employed to predict response to a casein-free diet. Several other studies did not support a significant association between consumption of casein/gluten and change of behavior in children with autism disorders (Millward, Ferriter, Calver, \& ConnellJones, 2008). Therefore, more detailed investigations are required to observe the effect of A1 $\beta$-casein on neurological disorders.

To reduce the consumption of A1 $\beta$-casein milk, A2 Corporation was established. The company principally focused on producing milk comprising only the A2 variant of $\beta$-casein. The farmers of certain countries such as New Zealand, the United Kingdom, and Australia are promoting A2 milk. Since the news concerning the advantage of A2 milk to human health is disseminated across the globe, many researchers have undergone genotyping of cattle in relation to A1 and $\mathrm{A} 2 \beta$-casein.

On contrary, European Union claimed that the findings provided with regard to the association of diseases with variants of milk are confounding. (Reijonen, Ilonen, Knip, \& Akerblom, 1991)suggested that the emerging case of diabetes is not associated with A1 $\beta$-casein milk only. Other genetic factors contribute to making an individual susceptible to various diseases (Beales et al., 2002). It can be claimed that the issues of the variant of $\beta$ casein in association with numerous diseases are confounding. Yet, adequate and rigorous research is needed to ascertain the negative effects of the A1 variant of $\beta$-casein on human health.

Based on the epidemiological data taken from humans or related to the in vitro animal trials, the consumption of $\mathrm{A} 1 \beta$-casein is also associated with a hypothesis that it augments the risk of several human diseases. The unfavorable role of the A1 protein variant is not yet clear and confirmed. $\beta$ casein gene and status of their allele in indigenous cattle are yet to be explored, warranting extensive research on its mechanism.

\section{Conclusions}

This study highlights that most of the cattle breeds of Asia share predominant A2 homozygous $\beta$-casein whereas cattle breeds of western countries possess genotypes of both A1 and A2 $\beta$-casein. Various research papers claim the association of A1 milk with several diseases. However, an ample number of research papers also seek stronger evidence for claiming A1 $\beta$-casein's detrimental effects on human health. Our paper found the confounding result with regard to the consumption of $\beta$-casein variants of milk to human health. Thus, additional research is needed to adequately characterize the two variants and their role in human health and nutrition.

\section{Future Perspectives}

Most of the native cattle of the Asian region are found to be comparatively robust and adaptive to harsh environmental conditions. While the milk obtained from indigenous cattle such as Lulu, Siri, and Achhami is rich in A2 $\beta$-casein, the population densities of these breeds are quite low and some are on the verge of extinction. Therefore, the goal of this review is to provide insights into the importance of native cattle of Nepal as well as of other Asian countries and the need for conservation of the indigenous gene pool. The status of $\beta$-casein A1/A2 alleles in bovine need to be analyzed to adopt an effective breeding policy as well as minimizing the risk of disseminating the A1 allele in Nepalese cattle. Genetic improvements of indigenous cattle should be prioritized through the selection and breeding of animals with desirable genotypes. There is a need for more intensive research highlighting the therapeutic and beneficial properties of A2 $\beta$ casein in human health. Since A2 protein is not associated with any health hazards, it is a beneficial approach to conserve indigenous cattle which provide A2-rich milk. Also, cows having different $\beta$-casein genotypes are found to have similar production and reproductive performance. Therefore, no significant negative impact is expected to occur on fertility or milk production while selecting animals based on the A2 genotype. We also highlight the importance of indigenous cattle breeds in human nutrition in Nepal and the need for their conservation. Government should encourage cattle farmers to conserve these indigenous breeds and should provide them financial assistance, if needed, to keep them motivated to preserve indigenous breed's purity.

\section{Authors' contributions}

NAG gave the overall idea of the review and each data is critically assessed by her. CS and PK wrote the overall review. SS and BRP helped in the collection of overall data required for the review paper

\section{Competing interests}

The authors declare that they have no competing interests.

\section{Acknowledgments}

We are thankful to Nepal Agricultural Research Council (NARC) for their constant support in making this review paper. Also, sincere gratitude is given to staff working in National Animal Breeding and Genetics Research Centre of NARC.

\section{References}

Atanasova, J., \& Ivanova, I. (2010). Antibacterial Peptides from Goat and Sheep Milk Proteins. Biotechnology \& Biotechnological Equipment, 24(2), 1799-1803. doi:10.2478/V10133-010-0049-8

Baldi, A., Ioannis, P., Chiara, P., Eleonora, F., Roubini, C., \& Vittorio, D. (2005). Biological effects of milk proteins and their peptides with emphasis on those related to the gastrointestinal ecosystem. Journal of Dairy Research, 72(S1), 66-72. doi:10.1017/S002202990500110X

Barnett, M. P. G., McNabb, W. C., Roy, N. C., Woodford, K. B., \& Clarke, A. J. (2014). Dietary A1 $\beta$-casein affects gastrointestinal transit time, 
dipeptidyl peptidase- 4 activity, and inflammatory status relative to A2 $\beta$ casein in Wistar rats. International Journal of Food Sciences and Nutrition, 65(6), 720-727. doi:10.3109/09637486.2014.898260

Barroso, A., Dunner, S., \& Cañón, J. (1999). Technical note: use of PCRsingle-strand conformation polymorphism analysis for detection of bovine beta-casein variants A1, A2, A3, and B. Journal of Animal Science, 77(10), 2629. doi:10.2527/1999.77102629x

Beales, P., Elliott, R., Flohé, S., Hill, J., Kolb, H., Pozzilli, P., ... Scott, F. (2002). A multi-centre, blinded international trial of the effect of A1 and A2 $\beta$-casein variants on diabetes incidence in two rodent models of spontaneous Type I diabetes. Diabetologia, 45(9), 1240-1246. doi:10.1007/s00125-002-0898-2

Bech, A.-M., \& Kristiansen, K. R. (1990). Milk protein polymorphism in Danish dairy cattle and the influence of genetic variants on milk yield. Journal of Dairy Research, 57(1), 53-62. doi:10.1017/S0022029900026601

Bell, S. J., Grochoski, G. T., \& Clarke, A. J. (2006). Health Implications of Milk Containing $\beta$-Casein with the A 2 Genetic Variant. Critical Reviews in Food Science and Nutrition, 46(1), 93-100. doi:10.1080/10408390591001144

Boztepe, S., Aytekin, İ., \& Şahin, Ö. (2018). A1 and A2 Bovine Milk, the Risk of Beta-casomorphin-7 and Its Possible Effects on Human Health: (II) Possible Effects of Beta-casomorphin-7 on Human Health. Selcuk Journal of Agricultural and Food Sciences, 32(3), 640-645. doi:10.15316/SJAFS.2018.147

Buie, T., Campbell, D. B., Fuchs, G. J., Furuta, G. T., Levy, J., VandeWater, J., ... Winter, H. (2010). Evaluation, Diagnosis, and Treatment of Gastrointestinal Disorders in Individuals with ASDs: A Consensus Report. Pediatrics, 125(Supplement 1), S1-S18. doi:10.1542/peds.2009-1878C

Cass, H., Gringras, P., March, J., McKendrick, I., O’Hare, A. E., Owen, L., \& Pollin, C. (2008). Absence of urinary opioid peptides in children with autism. Archives of Disease in Childhood, 93(9), 745-750. doi:10.1136/adc.2006.114389

Chessa, S., Bulgari, O., Rossoni, A., Ceriotti, G., \& Caroli, A. M. (2013).

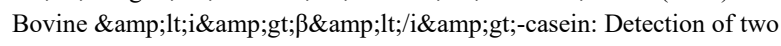
single nucleotide polymorphisms by bidirectional allele specific polymerase chain reaction (BAS-PCR) and monitoring of their variation. Open Journal of Animal Sciences, 03(01), 36-41. doi:10.4236/ojas.2013.31005

Chia, J. S. J., McRae, J. L., Kukuljan, S., Woodford, K., Elliott, R. B., Swinburn, B., \& Dwyer, K. M. (2017). A1 beta-casein milk protein and other environmental pre-disposing factors for type 1 diabetes. Nutrition \& Diabetes, 7(5), e274-e274. doi:10.1038/nutd.2017.16

Cieślińska, A., Fiedorowicz, E., Zwierzchowski, G., Kordulewska, N., Jarmołowska, B., \& Kostyra, E. (2019). Genetic Polymorphism of $\beta$ Casein Gene in Polish Red Cattle-Preliminary Study of A1 and A2 Frequency in Genetic Conservation Herd. Animals, 9(6), 377. doi:10.3390/ani9060377

Cieślińska, A., Kostyra, E., Kostyra, H., Oleński, K., Fiedorowicz, E., \& Kamiński, S. (2012). Milk from cows of different $\beta$-casein genotypes as a source of $\beta$-casomorphin-7. International Journal of Food Sciences and Nutrition, 63(4), 426-430. doi:10.3109/09637486.2011.634785

Clare, D. A., \& Swaisgood, H. E. (2000). Bioactive Milk Peptides: A Prospectus. Journal of Dairy Science, 83(6), 1187-1195. doi:10.3168/jds.S0022-0302(00)74983-6

Clemens, R. A. (2011). Milk A1 and A2 Peptides and Diabetes. In Milk and Milk Products in Human Nutrition (pp. 187-195). Basel: KARGER. doi:10.1159/000325584

Dai, R., Fang, Y., Zhao, W., Liu, S., Ding, J., Xu, K., ... Meng, H. (2016). Identification of alleles and genotypes of beta-casein with DNA sequencing analysis in Chinese Holstein cow. Journal of Dairy Research, 83(3), 312-316. doi:10.1017/S0022029916000303
Day, L., Williams, R. P. W., Otter, D., \& Augustin, M. A. (2015). Casein polymorphism heterogeneity influences casein micelle size in milk of individual cows. Journal of Dairy Science. doi:10.3168/jds.2014-9285

Dinc, H., Ozkan, E., Koban, E., \& Togan, I. (2013). Beta-casein A1/A2, kappacasein and beta-lactoglobulin polymorphisms in Turkish cattle breeds. Archives Animal Breeding, 56(1), 650-657. doi:10.7482/0003-9438-56065

Elliott, R. B., Harris, D. P., Hill, J. P., Bibby, N. J., \& Wasmuth, H. E. (1999). Type I (insulin-dependent) diabetes mellitus and cow milk: casein variant consumption. Diabetologia, 42(3), 292-296. doi:10.1007/s001250051153

Farrell, H. M., Jimenez-Flores, R., Bleck, G. T., Brown, E. M., Butler, J. E., Creamer, L. K., ... Swaisgood, H. E. (2004). Nomenclature of the Proteins of Cows' Milk-Sixth Revision. Journal of Dairy Science, 87(6), 16411674. doi:10.3168/jds.S0022-0302(04)73319-6

Ferretti, L., Leone, P., \& Sgaramella, V. (1990). Long range restriction analysis of the bovine casein genes. Nucleic Acids Research, 18(23), 68296833. doi:10.1093/nar/18.23.6829

Gorkhali, N. A., Sherpa, C., Budhathoki, N., GC, S., Lama, S., Pokharel, P., ... Sapkota, S. (2020). PCR Based Genotyping of Lulu Cattle of Nepal for A1, A2 Type Beta-caseins. Journal of Nepal Agricultural Research Council, 6, 56-61. doi:10.3126/jnarc.v6i0.28115

Gorkhali, N. A., Dhakal, A., Sapkota, S., Sherpa, C., Pokhrel, B., Kolachhapati, M., \& Bhattarai, N. (2020). Mitochondrial DNA polymorphisms in Nepalese Achhami cattle. Bangladesh Journal of Animal Science, 49(1), 22-28. doi:10.3329/bjas.v49i1.49374

Groenen, M. A. ., \& van der Poel, J. J. (1994). Regulation of expression of milk protein genes: a review. Livestock Production Science, 38(2), 61-78. doi:10.1016/0301-6226(94)90051-5

Gustavsson, F., Buitenhuis, A. J., Johansson, M., Bertelsen, H. P., Glantz, M., Poulsen, N. A., ... Andrén, A. (2014). Effects of breed and casein genetic variants on protein profile in milk from Swedish Red, Danish Holstein, and Danish Jersey cows. Journal of Dairy Science, 97(6), 3866-3877. doi:10.3168/jds.2013-7312

Haq, M. R. U., Kapila, R., Sharma, R., Saliganti, V., \& Kapila, S. (2014). Comparative evaluation of cow $\beta$-casein variants (A1/A2) consumption on Th2-mediated inflammatory response in mouse gut. European Journal of Nutrition, 53(4), 1039-1049. doi:10.1007/s00394-013-0606-7

He, M., Sun, J., Jiang, Z. Q., \& Yang, Y. X. (2017). Effects of cow's milk beta-casein variants on symptoms of milk intolerance in Chinese adults: a multicentre, randomised controlled study. Nutrition Journal, 16(1), 72. doi:10.1186/s12937-017-0275-0

Heck, J. M. L., Schennink, A., van Valenberg, H. J. F., Bovenhuis, H., Visker, M. H. P. W., van Arendonk, J. A. M., \& van Hooijdonk, A. C. M. (2009). Effects of milk protein variants on the protein composition of bovine milk. Journal of Dairy Science, 92(3), 1192-1202. doi:10.3168/jds.2008-1208

Jianqin, S., Leiming, X., Lu, X., Yelland, G. W., Ni, J., \& Clarke, A. J. (2015). Effects of milk containing only A2 beta casein versus milk containing both $\mathrm{A} 1$ and $\mathrm{A} 2$ beta casein proteins on gastrointestinal physiology, symptoms of discomfort, and cognitive behavior of people with self-reported intolerance to traditional cows' milk. Nutrition Journal, 15(1), 35. doi:10.1186/s12937-016-0147-z

Kamiński, S., Ruść, A., \& Cieślińska, A. (2006). A note on frequency of A1 and A2 variants of bovine beta-casein locus in Polish Holstein bulls. Journal of Animal and Feed Sciences, 15(2), 195-198. doi:10.22358/jafs/66892/2006

Kamiński, S., Cieślińska, A., \& Kostyra, E. (2007). Polymorphism of bovine beta-casein and its potential effect on human health. Journal of Applied Genetics, 48(3), 189-198. doi:10.1007/BF03195213

Kaskous, S. (2020). A1- and A2-Milk and Their Effect on Human Health. Journal of Food Engineering and Technology, 9(1), 15-21. doi:10.32732/jfet.2020.9.1.15

Kay, S.-I. S., Delgado, S., Mittal, J., Eshraghi, R. S., Mittal, R., \& Eshraghi, A. A. (2021). Beneficial Effects of Milk Having A2 $\beta$-Casein Protein: Myth or 
Reality? The Journal of Nutrition, 151(5), 1061-1072. doi: $10.1093 / \mathrm{jn} / \mathrm{nxaa} 454$

Ketto, I. A., Knutsen, T. M., Øyaas, J., Heringstad, B., Ådnøy, T., Devold, T. G., \& Skeie, S. B. (2017). Effects of milk protein polymorphism and composition, casein micelle size and salt distribution on the milk coagulation properties in Norwegian Red cattle. International Dairy Journal, 70, 55-64. doi:10.1016/j.idairyj.2016.10.010

Korhonen, H., \& Pihlanto, A. (2003). Food-derived Bioactive Peptides Opportunities for Designing Future Foods. Current Pharmaceutical Design, 9(16), 1297-1308. doi:10.2174/1381612033454892

Kost, N. V., Sokolov, O. Y., Kurasova, O. B., Dmitriev, A. D., Tarakanova, J. N., Gabaeva, M. V., ... Zozulya, A. A. (2009). $\beta$-Casomorphins-7 in infants on different type of feeding and different levels of psychomotor development. Peptides, 30(10), 1854-1860. doi:10.1016/j.peptides.2009.06.025

Liu, Z., \& Udenigwe, C. C. (2019). Role of food-derived opioid peptides in the central nervous and gastrointestinal systems. Journal of Food Biochemistry, 43(1), e12629. doi:10.1111/jfbc.12629

Malmström, H., Linderholm, A., Lidén, K., Storå, J., Molnar, P., Holmlund, G., ... Götherström, A. (2010). High frequency of lactose intolerance in a prehistoric hunter-gatherer population in northern Europe. $B M C$ Evolutionary Biology, 10(1), 89. doi:10.1186/1471-2148-10-89

Massella, E., Piva, S., Giacometti, F., Liuzzo, G., Zambrini, A. V., \& Serraino, A. (2017). Evaluation of bovine beta casein polymorphism in two dairy farms located in northern Italy. Italian Journal of Food Safety, 6(3). doi:10.4081/ijfs.2017.6904

McLachlan, C. N. S. (2001). $\beta$-casein A1, ischaemic heart disease mortality, and other illnesses. Medical Hypotheses, 56(2), 262-272. doi:10.1054/mehy.2000.1265

Milan, A. M., Shrestha, A., Karlström, H. J., Martinsson, J. A., Nilsson, N. J., Perry, J. K., ... Cameron-Smith, D. (2020). Comparison of the impact of bovine milk $\beta$-casein variants on digestive comfort in females selfreporting dairy intolerance: a randomized controlled trial. The American Journal of Clinical Nutrition, 111(1), 149-160. doi:10.1093/ajcn/nqz279

Miller, G. D., Jarvis, J. K., \& McBean, L. D. (2006). Handbook of Dairy Foods and Nutrition. CRC Press. doi:10.1201/9781420004311

Millward, C., Ferriter, M., Calver, S. J., \& Connell-Jones, G. G. (2008). Gluten- and casein-free diets for autistic spectrum disorder. Cochrane Database of Systematic Reviews. doi:10.1002/14651858.CD003498.pub3

Miluchova, M., Gabor, M., \& Trakovicka, A. (2014). Analysis of genetic structure in Slovak Pinzgau cattle using five candidate genes related to milk production traits. Genetika, 46(3), 865-875. doi:10.2298/GENSR1403865M

MOLEE, A., BOONEK, L., \& RUNGSAKINNIN, N. (2011). The effect of beta and kappa casein genes on milk yield and milk composition in different percentages of Holstein in crossbred dairy cattle. Animal Science Journal, 82(4), 512-516. doi:10.1111/j.1740-0929.2011.00879.x

Nedvídková, J., Kasafírek, E., Dlabač, A., \& Felt, V. (2009). Effect of BetaCasomorphin and Its Analogue on Serum Prolactin in the Rat. Experimental and Clinical Endocrinology \& Diabetes, 85(02), 249-252. doi:10.1055/s-0029-1210445

Pal, S., Woodford, K., Kukuljan, S., \& Ho, S. (2015). Milk Intolerance, BetaCasein and Lactose. Nutrients, 7(9), 7285-7297. doi:10.3390/nu7095339

Park, Y. W., \& Haenlein, G. F. W. (2021). A2 Bovine Milk and Caprine Milk as a Means of Remedy for Milk Protein Allergy. Dairy, 2(2), 191-201. doi:10.3390/dairy2020017

Phelan, M., Aherne, A., FitzGerald, R. J., \& O’Brien, N. M. (2009). Caseinderived bioactive peptides: Biological effects, industrial uses, safety aspects and regulatory status. International Dairy Journal, 19(11), 643654. doi:10.1016/j.idairyj.2009.06.001

Reddy, P. R. K., Reddy, A. N., Ramadevi, A., \& Kumar, D. S. (2016). Nutritional Significance of Indigenous Cow Milk With Regard To a2 B Casein - an Overview, 5(5), 3376-3380.
Reijonen, H., Ilonen, J., Knip, M., \& Akerblom, H. K. (1991). HLA-DQB1 Alleles and Absence of Asp 57 as Susceptibility Factors of IDDM in Finland. Diabetes, 40(12), 1640-1644. doi:10.2337/diab.40.12.1640

SAKAGUCHI, M., KOSEKI, M., WAKAMATSU, M., \& MATSUMURA, E. (2003). Effects of $\beta$-Casomorphin-5 on Passive Avoidance Response in Mice. Bioscience, Biotechnology, and Biochemistry, 67(11), 2501-2504. doi:10.1271/bbb.67.2501

Schanbacher, F. L., Talhouk, R. S., Murray, F. A., Gherman, L. I., \& Willett, L. B. (1998). Milk-Borne Bioactive Peptides. International Dairy Journal, 8(5-6), 393-403. doi:10.1016/S0958-6946(98)00062-4

Sheng, X., Li, Z., Ni, J., \& Yelland, G. (2019). Effects of Conventional Milk Versus Milk Containing Only A2 $\beta$-Casein on Digestion in Chinese Children: A Randomized Study. Journal of Pediatric Gastroenterology \& Nutrition, 69(3), 375-382. doi:10.1097/MPG.0000000000002437

Singh, N. K., Kour, S., \& Sharma, N. (2016). Impact of A1/A2 forms of Cow's Milk on Human Health-A review. Journal of Animal Research, 6(6), 923. doi:10.5958/2277-940X.2016.00132.7

Sodhi, M., Kataria, R., Joshii, B., Mukesh, M., \& Mishra, B. (2012). Milk proteins and human health: A1/A2 milk hypothesis. Indian Journal of Endocrinology and Metabolism, 16(5), 856. doi:10.4103/22308210.100685

Sodhi, M., Kataria, R. S., Niranjan, S. K., K., P., Verma, P., Swami, S. K., ... Mukesh, M. (2018). Sequence Characterisation and Genotyping of Allelic Variants of Beta Casein Gene Establishes Native Cattle of Ladakh to be a Natural Resource for A2 Milk. Defence Life Science Journal, 3(2), 177. doi:10.14429/dlsj.3.12574

Sun, Z., \& Cade, J. R. (1999). A Peptide Found in Schizophrenia and Autism Causes Behavioral Changes in Rats. Autism, 3(1), 85-95. doi: $10.1177 / 1362361399003001007$

Sun, Z., Zhang, Z., Wang, X., Cade, R., Elmir, Z., \& Fregly, M. (2003). Relation of $\beta$-casomorphin to apnea in sudden infant death syndrome. Peptides, 24(6), 937-943. doi:10.1016/S0196-9781(03)00156-6

Tailford, K. (2003). A casein variant in cow's milk is atherogenic. Atherosclerosis, 170(1), 13-19. doi:10.1016/S0021-9150(03)00131-X

Teschemacher, H. (2003). Opioid Receptor Ligands Derived from Food Proteins. Current Pharmaceutical Design, 9(16), 1331-1344. doi:10.2174/1381612033454856

Thorsdottir, I., Birgisdottir, B. E., Johannsdottir, I. M., Harris, D. P., Hill, J., Steingrimsdottir, L., \& Thorsson, A. V. (2000). Different beta -Casein Fractions in Icelandic Versus Scandinavian Cow's Milk May Influence Diabetogenicity of Cow's Milk in Infancy and Explain Low Incidence of Insulin-Dependent Diabetes Mellitus in Iceland. PEDIATRICS, 106(4), 719-724. doi:10.1542/peds.106.4.719

Trivedi, M. S., Shah, J. S., Al-Mughairy, S., Hodgson, N. W., Simms, B., Trooskens, G. A., ... Deth, R. C. (2014). Food-derived opioid peptides inhibit cysteine uptake with redox and epigenetic consequences. The Journal of Nutritional Biochemistry, 25(10), 1011-1018. doi:10.1016/j.jnutbio.2014.05.004

Trompette, A., Claustre, J., Caillon, F., Jourdan, G., Chayvialle, J. A., \& Plaisancié, P. (2003). Milk Bioactive Peptides and $\beta$-Casomorphins Induce Mucus Release in Rat Jejunum. The Journal of Nutrition, 133(11), 34993503. doi: $10.1093 / \mathrm{jn} / 133.11 .3499$

Truswell, A. S. (2005). The A2 milk case: a critical review. European Journal of Clinical Nutrition, 59(5), 623-631. doi:10.1038/sj.ejcn.1602104

ul Haq, M. R., Kapila, R., Shandilya, U. K., \& Kapila, S. (2014). Impact of Milk Derived $\beta$-Casomorphins on Physiological Functions and Trends in Research: A Review. International Journal of Food Properties, 17(8), 1726-1741. doi:10.1080/10942912.2012.712077

Virtanen, S. M., Laara, E., Hypponen, E., Reijonen, H., Rasanen, L., Aro, A., ... Akerblom, H. K. (2000). Cow's milk consumption, HLA-DQB1 genotype, and type 1 diabetes: a nested case-control study of siblings of children with diabetes. Childhood diabetes in Finland study group. Diabetes, 49(6), 912-917. doi:10.2337/diabetes.49.6.912 
Visker, M. H. P. W., Dibbits, B. W., Kinders, S. M., van Valenberg, H. J. F., van Arendonk, J. A. M., \& Bovenhuis, H. (2011). Association of bovine $\beta$ casein protein variant I with milk production and milk protein composition. Animal Genetics, 42(2), 212-218. doi:10.1111/j.1365-2052.2010.02106.x

Wasilewska, J., Sienkiewicz-Szłapka, E., Kuźbida, E., Jarmołowska, B., Kaczmarski, M., \& Kostyra, E. (2011). The exogenous opioid peptides and DPPIV serum activity in infants with apnoea expressed as apparent life threatening events (ALTE). Neuropeptides, 45(3), 189-195. doi:10.1016/j.npep.2011.01.005

Whiteley, P., Haracopos, D., Knivsberg, A.-M., Reichelt, K. L., Parlar, S., Jacobsen, J., ... Shattock, P. (2010). The ScanBrit randomised, controlled, single-blind study of a gluten- and casein-free dietary intervention for children with autism spectrum disorders. Nutritional Neuroscience, 13(2), 87-100. doi:10.1179/147683010X12611460763922

Woodford, K. (2008). Open public forum A1 Beta-casein, Type 1 diabetes and links to other new world illnesses. Diabetes Research and Clinical Practice, 79, S3. doi:10.1016/S0168-8227(08)70650-8

Woodford, K. B. (2006). A critique of Truswell's A2 milk review. European Journal of Clinical Nutrition, 60(3), 437-439. doi:10.1038/sj.ejcn.1602322

$\mathrm{Xu}, \mathrm{R}$. (1998). Bioactive peptides in milk and their biological and health implications. Food Reviews International, 14(1), 1-16. doi:10.1080/87559129809541147
Yadav, S., Yadav, N. D. S., Gheware, A., Kulshreshtha, A., Sharma, P., \& Singh, V. P. (2020). Oral Feeding of Cow Milk Containing A1 Variant of $\beta$ Casein Induces Pulmonary Inflammation in Male Balb/c Mice. Scientific Reports, 10(1), 8053. doi:10.1038/s41598-020-64997-Z

Yin, H., Miao, J., Ma, C., Sun, G., \& Zhang, Y. (2012). $\beta$-Casomorphin-7 Cause Decreasing in Oxidative Stress and Inhibiting NF-кB-iNOS-NO Signal Pathway in Pancreas of Diabetes Rats. Journal of Food Science, 77(2), C278-C282. doi:10.1111/j.1750-3841.2011.02577.x

Yin, H., Miao, J., \& Zhang, Y. (2010). Protective effect of $\beta$-casomorphin-7 on type 1 diabetes rats induced with streptozotocin. Peptides, 31(9), 17251729. doi:10.1016/j.peptides.2010.05.016

Zoghbi, S., Trompette, A., Claustre, J., Homsi, M. El, Garzón, J., Jourdan, G., ... Plaisancié, P. (2006). $\beta$-Casomorphin-7 regulates the secretion and expression of gastrointestinal mucins through a $\mu$-opioid pathway. American Journal of Physiology-Gastrointestinal and Liver Physiology, 290(6), G1105-G1113. doi:10.1152/ajpgi.00455.2005

Zong, Y.-F. (2007). Effects of intra-gastric beta-casomorphin-7 on somatostatin and gastrin gene expression in rat gastric mucosa. World Journal of Gastroenterology, 13(14), 2094. doi:10.3748/wjg.v13.i14.2094. 